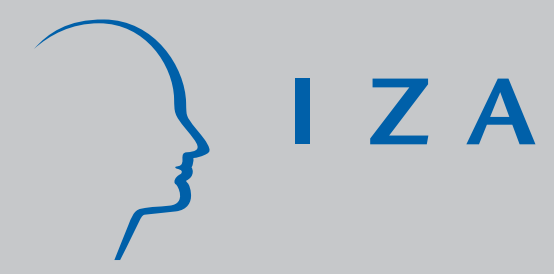

IZA DP No. 1704

Does Obesity Hurt Your Wages

More in Dublin than in Madrid?

Evidence from ECHP

Béatrice d'Hombres

Giorgio Brunello

August 2005 


\title{
Does Obesity Hurt Your Wages More in Dublin than in Madrid? Evidence from ECHP
}

\author{
Béatrice d'Hombres \\ University of Padova \\ Giorgio Brunello \\ University of Padova, CESifo \\ and IZA Bonn
}

\section{Discussion Paper No. 1704 \\ August 2005}

\author{
IZA \\ P.O. Box 7240 \\ 53072 Bonn \\ Germany \\ Phone: +49-228-3894-0 \\ Fax: +49-228-3894-180 \\ Email: iza@iza.org
}

\begin{abstract}
Any opinions expressed here are those of the author(s) and not those of the institute. Research disseminated by IZA may include views on policy, but the institute itself takes no institutional policy positions.
\end{abstract}

The Institute for the Study of Labor (IZA) in Bonn is a local and virtual international research center and a place of communication between science, politics and business. IZA is an independent nonprofit company supported by Deutsche Post World Net. The center is associated with the University of Bonn and offers a stimulating research environment through its research networks, research support, and visitors and doctoral programs. IZA engages in (i) original and internationally competitive research in all fields of labor economics, (ii) development of policy concepts, and (iii) dissemination of research results and concepts to the interested public.

IZA Discussion Papers often represent preliminary work and are circulated to encourage discussion. Citation of such a paper should account for its provisional character. A revised version may be available directly from the author. 
IZA Discussion Paper No. 1704

August 2005

\section{ABSTRACT}

\section{Does Obesity Hurt Your Wages More in Dublin than in Madrid? Evidence from ECHP*}

We use data from the European Community Household Panel to investigate the impact of obesity on wages in 9 European countries, ranging from Ireland to Spain. We find that the common impact of obesity on wages is negative and statistically significant, independently of gender. Given the nature of European labor markets, however, we believe that a common impact is overly restrictive. When we allow this impact to vary across countries, we find a negative relationship between the BMI and wages in the countries of the European "olive belt" and a positive relationship in the countries of the "beer belt". We speculate that such difference could be driven by the interaction between the weather, BMI and individual (unobserved) productivity.

JEL Classification: I12, J3

Keywords: $\quad$ wages, body mass index, Europe

Corresponding author:

Giorgio Brunello

Università di Padova

Dipartimento di Scienze Economiche

Via del Santo 33

35100 Padova

Italy

Email: giorgio.brunello@unipd.it

\footnotetext{
*We are grateful to Dean Lillard, Lorenzo Rocco and Guglielmo Weber for advice, and to the audience at EPUNet-2005 for useful comments. The ECHP data used in this paper are available at the Department of Economics, University of Padova, under contract 14/99.
} 


\section{Introduction}

There is a growing literature that documents the relationship between physical appearance and labour market outcomes in developed countries (Cawley, 2004, Cawley and Danziger, 2000, Hamermesh and Biddle, 1994, Averett and Korenman, 1996, Register and Williams, 1990). Some of these studies show that obesity is an handicap to social advancement, especially for women. Most of the evidence of the negative correlation between obesity and wages is for the US, but there are a few recent studies which address the economic impact of obesity in Europe (see Fahr, 2003, and Sousa, 2005²).

The consequences of obesity are numerous, both in terms of an increase in health problems (diabetes, cardiovascular diseases, hypertension, etc) and in terms of the adverse impact on the quality of life. On the one hand, obesity may hamper productivity. On the other hand, when labour markets are imperfect and there is asymmetric information about individual productivity, obese individuals may be statistically discriminated if employers believe that they are less productive than the rest of the population (Aigner and Cain, 1977).

Taste discrimination by employers and /or customers, and cultural factors may also result in differentiated treatment based on physical attributes (Becker, 1957). In spite of monetary unification, Europe differs broadly in culture, values and social customs. Suppose that, ceteris paribus, obesity attracts a negative premium in Madrid and a positive premium in Dublin. In a perfectly mobile labor market, we would expect mobility flows from Madrid to Dublin to arbitrage away these differences. If mobility costs are substantial, however, either because of language or because of social networks, these differences will persist over time.

\footnotetext{
${ }^{1}$ Both studies use the European Community Household Panel. Fahr, 2003 ignores the potential endogeneity of the body mass index in wage regressions. Sousa, 2005, use matching techniques and focuses on the impact of the body mass index on labor force participation. Cawley et al, 2005, investigate the relationship between obesity and earnings in the US and Germany.
} 
In this paper, we explore the impact of the body mass index (henceforth $B M I$ ) - measured as weight over the square of height - on wages in nine European countries, using information from the European Community Household Panel, a dataset explicitly designed to favour international comparisons. Any such exploration must confront the fact that a positive (or negative) correlation between $B M I$ and wages need not imply a causal relationship running from the former to the latter. The uncovered correlation could in fact reflect both that obesity affects wages and that wages affect obesity. Most of the existing empirical literature has tried to deal with the identification of the causal relationship between obesity and wages, and our comparative exercise is no exception to this pattern.

We start by reporting for the pooled sample ordinary least squares estimates, which show that the correlation of obesity and earnings varies with gender - positive for males, negative for females. However, OLS estimates are likely to be biased by the endogeneity of $B M I$. Following Cawley, 2000, 2004 and Cawley et al, 2005, we use information on the BMI of parents, siblings, and children to construct an instrument of individual BMI. Our estimates based on instrumental variables show that obesity hurts wages, independently of gender.

We also find that the impact of obesity on wages varies across the countries of Europe, and that this variation exhibits interesting patterns. For instance, obesity affects wages negatively in the countries with lower GDP per capita and positively in the countries with higher GDP. Perhaps more interestingly, we find that the impact of obesity on wages is negative in the warmer countries of the "olive belt" of Europe - Spain, Greece, Italy and Portugal - and positive in the colder countries of the "beer belt" (Austria, Ireland, Denmark, Belgium and Finland). We speculate that the impact of being overweight or obese on productivity might depend on the weather: negative in warmer climates and positive in colder environments.

The paper is organized as follows. Section 1 introduces the empirical re- 
lationship between obesity and wages. Section 2 describes the data. Results are presented and discussed in Section 3. Conclusions follow.

\section{The Empirical Relationship between Obesity and Wages}

We model individual hourly wages $w$ as follows:

$$
\left\{\begin{array}{c}
w_{i t}=\beta_{0}+X_{i t} \beta_{1}+B M I_{i t} \gamma_{1}+\eta_{i t}, \quad i=1, \ldots, N, \quad t=1, \ldots, T \\
\eta_{i t}=f_{i}+\varepsilon_{i t},
\end{array}\right.
$$

where the subscript $i$ is for the individual, $t$ is for time, $X_{i t}$ is a $[N T \times K]$ vector of time-varying explanatory variables, $B M I_{i t}$ is the body mass index - defined as individual weight divided by the square of height, $\varepsilon_{i t}$ is the disturbance term and $f_{i}$ the unobserved individual effect. Standard OLS estimates yield unbiased results if $E\left[B M I_{i t}^{\prime} \eta_{i t}\right]=0$ holds. However, as reviewed in detail by Cawley, 2004, there are at least three reasons why the orthogonality condition fails. First, there is potential reverse causality, because obesity is higher among those with low income, who have a higher intake of cheap food rich in fat and sugar. Second, unobservable individual effects associated to genetic and to non-genetic factors - such as ability and parental background - are correlated both with earnings and with the respondents's weight, i.e. $E\left[B M I_{i t}^{\prime} f_{i}\right] \neq 0$. Finally, the body mass index can be measured with error - as we rely on self-reported measures of weight and height.

Gortmarker et al, 1993, Sargent and Blantchflower, 1994, and Averett and Korenman, 1996, address reverse causality by replacing the contemporaneous body mass index with its seven years lagged value. Since our data cover a relatively short span of time, we cannot use the $B M I$ lagged seven years, as done in the literature. Averett and Korenman, 1996, Behrman and Rosenzweig, 2001, Conley and Glauber, 2005, use information on siblings and twins to remove the common household effect - due to both genetic 
and non - genetic factors. Baum and Ford, 2004, and Cawley, 2004 rely on fixed effect estimators to control for unobservable individuals effects. We also use the fixed effects estimator, but we do not find it very convincing in the current context: since the individual variation of the body mass index over a short time interval is likely to be dominated by measurement error, using such method is unlikely to pick up any significant relationship between obesity and wages.

Pagan and Davila, 1997, Cawley, 2000, 2004 and Cawley et al, 2005 use instrumental variables ${ }^{2}$. Pagan and Davila select indicators of health problems, such as self-esteem and family poverty, as instruments. However, as argued by Cawley, 2004, these instruments are likely to be correlated with earnings, and do not satisfy the orthogonality condition. Behrman and Rosenzweig, 2001, use a twin estimator and select as instrument the lagged weight of $B M I$ to simultaneously correct for reverse causality and endogeneity. Cawley, 2000, 2004 select as instrument the BMI of a biological family member $^{3}$. Finally, Cawley et al, 2005, compare the relationship between obesity and earnings in the US and Germany, and use the weight of a child or of a parent as instruments ${ }^{4}$.

Does the BMI of a biological family member satisfies the two necessary conditions for instrument validity? As reviewed by Cawley, 2004, members of a biological family share part of their genes, which ensures a strong correlation between the endogenous variable and its instrument. In other words, the selected instrument is unlikely to be weak. Turning to orthogonality, the $B M I$ of a biological family member fails to qualify as a valid instrument if it is correlated with the error term in the wage regression. This could happen if there are nongenetic unobserved effects which affect both

\footnotetext{
${ }^{2}$ Recently, Sousa (2005) studies the impact of weight on employment and labour maket participation in Europe, using a matching estimator.

${ }^{3}$ Biological members include parents, siblings and children.

${ }^{4}$ Note also that Cawley, 2000, 2004, correct the self-reported measures of weight and height using the methodology outlined by Lee and Sepanski, 1995, and Bound et al, 2002.
} 
the $B M I$ of parents, siblings and children, and the wage residual in (1). Cawley, 2004, argues extensively that this is unlikely, quoting evidence from adoption studies, which suggest that the correlation of weight within families is due to genetic factors rather than to family environment. Moreover, Vogler et al, 1995, Grilo and Pogue-Geile, 1991, find no evidence that the common family environment influences the body mass index, which suggests that the $B M I$ of a family member is unlikely to be correlated with wage residual via unobserved nongenetic effects. If we are prepared to assume that unobservable genetic factors affecting individual earnings are orthogonal to the transmitted genetic variation in weight, as Cawley does, the orthogonality condition holds and the $B M I$ of a biological family member is a valid instrument of individual $B M I$.

\section{Data and Descriptive Statistics}

Our data are drawn from the European Community Household Panel (ECHP), a dataset designed and coordinated by Eurostat, the European Statistical Office. The ECHP is an harmonized cross-national longitudinal survey covering all countries in the European Union from 1994 to 2001, with a focus on household income and living conditions, and with information on individual health, education and employment status.

We only consider countries where information on weight and height is available - Denmark, Belgium, Ireland, Italy, Greece, Spain, Portugal, Austria and Finland - and focus on employees working at least 15 hours per week and aged between 18 and 65 years over the period $1998-2001^{5}$. Our key indicator is the Body Mass Index, defined as the weight (in kilograms) divided by squared height (in meters), which is highly correlated with direct measures of body fat and is widely used in epidemiology and medicine ${ }^{6}$. We

\footnotetext{
${ }^{5}$ We have no information about weight for the previous years of the panel.

${ }^{6}$ Several other measures have been used in the literature, such as the weight and height, or the percentage of obese individuals. Authors often use the three indicators - underweight, overweight and obese - for clinical weight specification. In addition, Harper, 2000
} 
eliminate potential outliers by restricting our sample further to include only individuals with a $B M I$ above 15 and lower than 35 .

Table 1 provides summary statistics, separately for men and women. An individual is considered as underweight, overweight and obese if her $B M I$ is below 18.5, between 25 and 30 and equal or higher than 30 respectively. Males are more likely to be overweight and obese than females: $43 \%$ and $7 \%$ of males are overweight and obese respectively, compared to $21 \%$ and $5 \%$ for females. The prevalence of obesity varies in a substantial way across countries. The table shows that $7 \%$ or more of female respondents are obese in Denmark and Finland, compared to $2 \%$ in Italy. Similarly, $28 \%$ of females are overweight in Finland, compared to $16 \%$ in Spain. Differences are marked also for males: 50\% of Greek males are overweight, compared to $37 \%$ in Belgium. The highest percentage of obese males is found in Spain and Finland (9\% and 10\%), and the lowest in Italy (5\%).

\section{Results}

Figures 1 and 2 report the semi-parametric estimates of the impact of the $B M I$ on the log hourly wage, after having partialled out age, time and country effects. Both figures suggest that the relationship between wages and $B M I$ is decreasing, independently of gender.

In the empirical estimates, we pool the available data over countries and years. Notice that the $B M I$ has the potential of affecting individual earnings both directly, by influencing productivity or because of wage discrimination, and indirectly, via its impact on educational attainment and job allocation.

use indicators of the location of the respondent in the gender distribution of BMI. This is probably relevant when social norms determine how an invidividual is viewed by the society. 
Figure 1: Semi-parametric estimate of the effect of BMI on log hourly wage, Males

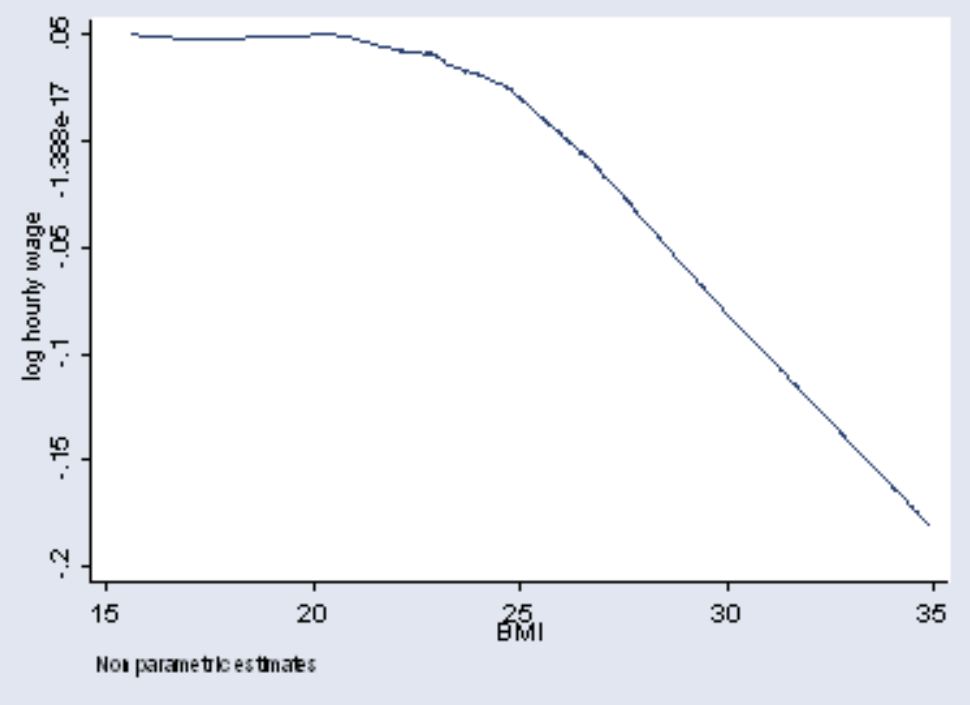

Figure 2: Semi-parametric estimate of the effect of BMI on log hourly wage, Females

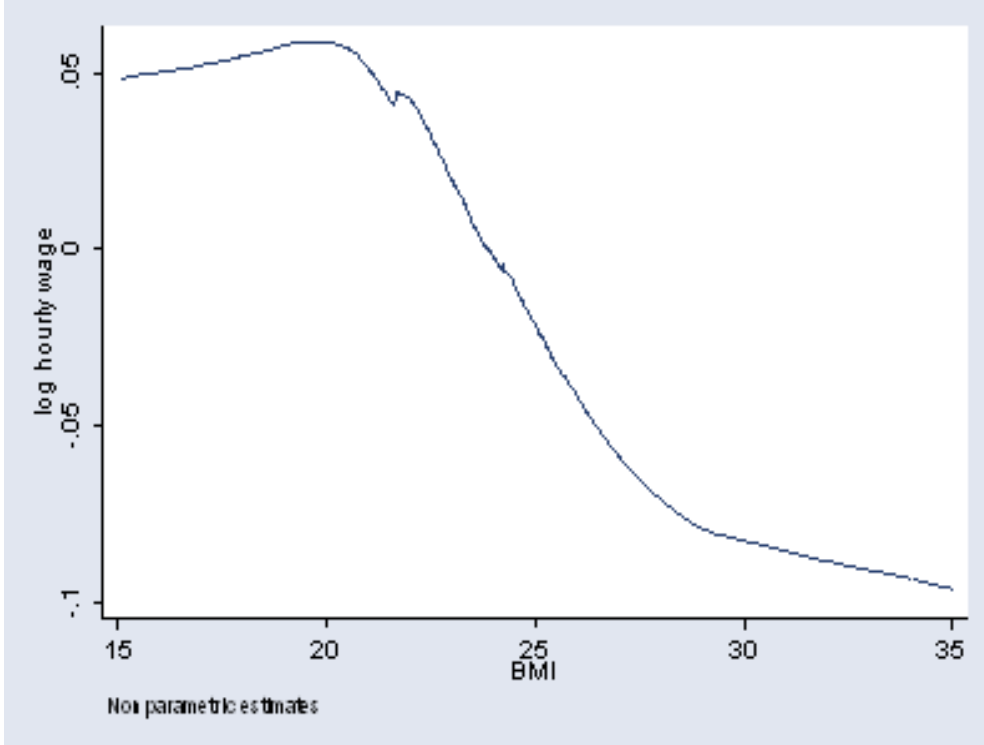


Table 1: Summary statistics, ECHP, 1998-2001

\begin{tabular}{lcccccc}
\hline \hline \multicolumn{3}{c}{ FEMALES } & \multicolumn{3}{c}{ MALES } \\
\hline & BMI & overw & obese & BMI & overw & obese \\
\hline Full sample & 23.31 & 0.21 & 0.05 & 25.36 & 0.43 & 0.07 \\
& & & & & & \\
Denmark & 23.98 & 0.25 & 0.07 & 25.32 & 0.43 & 0.08 \\
Belgium & 22.80 & 0.16 & 0.04 & 24.98 & 0.37 & 0.08 \\
Ireland & 23.41 & 0.22 & 0.05 & 25.09 & 0.42 & 0.06 \\
Italy & 22.56 & 0.17 & 0.02 & 25.05 & 0.40 & 0.05 \\
Greece & 23.32 & 0.22 & 0.04 & 25.71 & 0.50 & 0.06 \\
Spain & 22.79 & 0.16 & 0.04 & 25.74 & 0.45 & 0.10 \\
Portugal & 23.80 & 0.24 & 0.06 & 25.39 & 0.43 & 0.07 \\
Austria & 23.17 & 0.21 & 0.04 & 25.17 & 0.40 & 0.07 \\
Finland & 24.20 & 0.28 & 0.08 & 25.49 & 0.42 & 0.09 \\
\hline \hline
\end{tabular}

Note: Overw: BMI between 25 and 30. Obese: BMI equal or higher than 30.

Source : ECHP, 1998-2001.

In order to distinguish between direct and indirect effects, we follow Persico et al, 2004, and estimate first wage equations which include among the regressors individual BMI and variables not affected by the BMI, such as age and time and country dummies. We then add additional controls education, household composition, health and current smoking habits. In the richest specification, we also include regional, occupation and industry dummies.

\subsection{OLS estimates}

The OLS estimates - weighted with the longitudinal ECHP weights - are reported in the first part of Table 2, separately for males and females ${ }^{7}$. The specification in the first and fourth columns includes the $B M I$, age and age squared, and country and time dummies. The coefficient associated with BMI turns out to be precisely estimated, negative and equal to -0.016

\footnotetext{
${ }^{7}$ The full results are in Table 6 of the Appendix.
} 
for females and not statistically significant for males. According to these estimates, a $10 \%$ increase in the $B M I$ of females from its mean value reduces their $\log$ hourly wages by $3.72 \%$. Since the specification is very parsimonious - we do not control, for instance, for the negative effect of obesity on health this effect can be considered as an upper bound on the wage penalty suffered by heavier females.

In columns (2) and (5) of the table, we add variables related to human capital investment and household characteristics, such as education, marital status and the presence of children younger than 12. Childbearing is usually associated with an increase in weight and with specific labour market outcomes. At least for women, education is negatively correlated with weight, this inverse relationship being due in part to the higher frequency of weight monitoring and to different behavioral patterns among more educated people (see Wardle and Griffith, 2001).

We also include three health variables, a dummy equal to 1 if the individual is in poor or bad health, a dummy equal to 1 if the individual is hampered in her daily activity by illness, and the number of cigarettes smoked. Studies have shown that the prevalence of health problems is higher for the obese than for the rest of the population (Michaud and Van Soest, 2005) and that obesity may limit labour supply. Smoking habits can affect current productivity - for instance because of the breaks from work required by the act of smoking- and are negatively correlated with weight (Molarius et al, 1997). ${ }^{8}$

When we add this set of explanatory variables, the estimated impact of $B M I$ on the log hourly wage remains negative and statistically significant for females and becomes positive and statistically significant for males ${ }^{9}$. Finally,

\footnotetext{
${ }^{8}$ Smoking also controls for unobservable heterogeneity in the individual discount rate.

${ }^{9}$ The impact of $B M I$ on earnings could vary by occupation. To check this, we reestimate the wage equation separately for manual occupations and non-manual occupations. The results are not reported, but the coefficient associated with $B M I$ is always positive, albeit statistically significant only for the case of manual workers. The coefficient associated with BMI is equal to 0.0030 for manual labour and to 0.0013 for non-manual
} 
we add in the third and sixth columns of the table occupation, industry and regional dummies. Physical activity is inversely associated with $B M I$, in particular for men (Martinez-Gonzales et al, 1999, Stam-Moraga, 1999), and occupations that are demanding in terms of physical strength are less remunerated in the labor market. The inclusion of these dummies affects the coefficient associated with $B M I$ for both males and females. More precisely, a $10 \%$ increase in mean $B M I$ reduces wages by a much smaller $0.23 \%$ for females, and raises male wages by $1 \%$. As suggested by McLean and Moon, 1980, the widespread positive effect for males could be due to the presence of a "portly banker effect", as larger size may generate a "non verbal signal" of power, strength, or capability, which commands respect from co-workers and employers.

Our results are consistent with previous literature. Cawley et al, 2005, also identify a positive and statistically significant association between wages and weight among US males and a negative relationship among US females. However, the magnitude of the coefficients associated to $B M I$ is smaller in our case, both for males and females. For the reasons discussed above, the uncovered correlations are plagued by the presence of unobservables and by reverse causality running from wages to $B M I^{10}$. In the next two subsections we try to deal with these issues, starting briefly with the fixed effects estimator and turning next to instrumental variables.

\section{2 $\quad$ Fixed effects estimates}

Since OLS estimates are biased because of the correlation between the $B M I$ and unobservables, one option is to remove time invariant individual effects

occupations.

${ }^{10}$ Note that our results are potentially subject to a sample selection bias since labour market participation depend on unobservable individual characteristics. We use the classic Heckman's method (1979) to correct for sample selection bias, but find no sensible difference in the results. Results are available from the authors upon request. 
Table 2: OLS estimates, by gender

\begin{tabular}{|c|c|c|c|c|c|c|}
\hline & \multicolumn{3}{|c|}{ 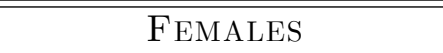 } & \multicolumn{3}{|c|}{ MALES } \\
\hline & & - OLS & & & OLS & \\
\hline & 1 & 2 & 3 & 4 & 5 & 6 \\
\hline BMI & $\begin{array}{c}-0.014 \\
12.69\end{array}$ & $-\underset{6.73}{0.005}$ & -0.001 & $\begin{array}{c}-0.001 \\
1.17\end{array}$ & $\begin{array}{l}0.003 \\
4.06\end{array}$ & $\begin{array}{c}0.004 \\
\dot{5} .26\end{array}$ \\
\hline Obs. & & 35505 & & & 47743 & \\
\hline
\end{tabular}

Note: $\overline{\text { Source: ECHP } 1998-2001 \text {. Estimates weighted with the longitudinal }}$ individual weights provided by ECHP. White heteroskedasticity-consistent absolute value of t-statistic below coefficients. Columns 1 and 4: Other regressors include age, age squared, country dummies and time dummies. Columns 2 and 5: 1 and 4+educational level attainment dummies (secondary and tertiary), indicators for the presence of children under 12, marital status, part-time, health situation, current smoking habits. Columns 3 and 6: 2 and 5+ regional, occupation and activity dummies.

by using a fixed effects estimator ${ }^{11}$. If we do so for the richest specification, the estimated coefficient associated to $B M I$ is not statistically significant both for females $(-0.001$ with a $t$-value of 0.19$)$ and for males $(0.000$ with $t$-value of 0.03). A word of caution is needed on the use of fixed effects estimates in the current context. The "within" transformation operated by the fixed effect estimator results in a substantial reduction in the variance of the BMI, which goes from $\sigma_{h}^{2}=3.37$ in levels to $\sigma_{\tilde{h}}^{2}=1.35$ in deviations with respect to individuals-specific means. Basing identification on individual variation over time results in a substantial loss in variance, and in the insignificant coefficients associated to the $B M I$ variable. In addition, as mentioned earlier, we face a measurement error problem which attenuates the estimate of the coefficient associated with $B M I$. Attenuation is more

\footnotetext{
${ }^{11}$ The individual fixed effect estimator has been used by Baum and Ford, 2004 and Cawley, 2004. In addition, Conley and Glauber, 2005, Averett and Korenman, 1996 rely on differences between siblings while Behrman and Rosensweig, 2001 use MZ twins fixed effects.
} 
important when the true variance of the variable is low. In summary, we fear that the estimates of the impact of $B M I$ on wages based on the fixed effects estimator is largely driven by noisy variations in the body mass index. Therefore, we turn to IV estimates.

\subsection{IV estimates}

We instrument individual $B M I$ with the $B M I$ of a biological family member, defined as a parent, child or sibling. For individuals with several available family members, we average out all available $B M I s$. For example, when an individual has two parents and three siblings, we take the unweighted average of the average $B M I$ of the parents and the average $B M I$ of the siblings. Since the European Community Household Panel does not explicitly report parental and sibling information for each interviewed individual, we need to reconstruct this information by linking records of individuals belonging to the same household. This exercise is not possible, for instance, for one person households with deceased parents, or for couples with no children and no living parents, or for households without parents or siblings currently alive. Therefore, our instrument can only be computed for a subsample of individuals. As detailed in the Data Appendix, the percentage of missing values is highest in Denmark, Finland and Belgium.

We have argued at length above about the validity of the selected instrument. We check weakness by regressing $B M I$ on the full set of explanatory variables plus our instrument and test whether the inclusion of the latter can be rejected by an $F$ test. It turns out that the value of the $F$ statistic is well above the threshold value of 10, indicated by Stock and Staiger, 1997, as the rule of thumb criterion to establish instrument weakness. We conclude that our instrument is not weak in a statistical sense ${ }^{12}$.

Our IV estimates are reported in the first part of Table 3. To ease comparison, we also report OLS estimates computed on the same sub-sample.

\footnotetext{
${ }^{12}$ The results of the first step regression are in Table 7 of the Appendix.
} 
Table 3: IV estimates, by gender

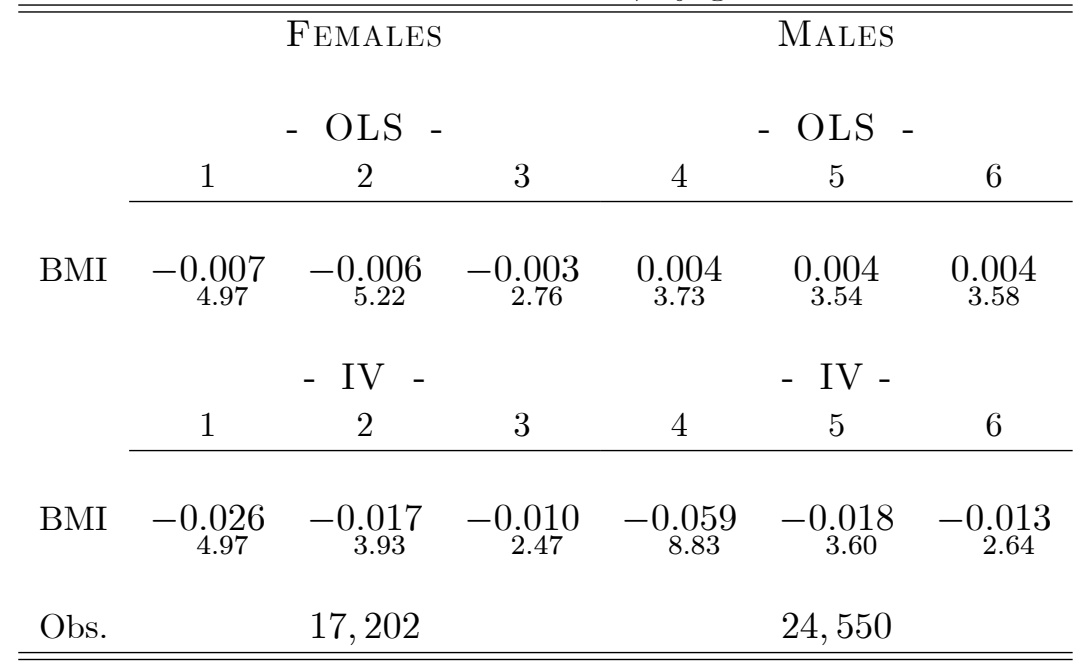

Note: see Table 2 .

Independently of gender, the estimated relationship between $B M I$ and earnings is negative and statistically significant both for males and for females. IV estimates generate also larger coefficients - in absolute value - than OLS estimates, because they eliminate the attenuation bias associated to measurement error. Our results for females are consistent with those by Cawley et al, 2005 for the US and Germany: they find that the $I V$ coefficient associated with $B M I$ is negative for females and of higher magnitude than the $O L S$ coefficient ${ }^{13}$. Conversely, the results for males contrast with those by Cawley and associates, who find that the impact of $B M I$ on male wages is no longer statistically significant after controlling for endogeneity.

One possible reading of our findings is that $O L S$ estimates are biased upwards by the positive correlation between unobservables - such as motivation or perseverance - and the $B M I$ : heavier individuals compensate their weight with unobservable characteristics (for the econometrician) that are

\footnotetext{
${ }^{13}$ Cawley, 2000 obtains similar results for white females in US. In contrast, the coefficient associated with BMI is no longer significant for Black females and Hispanic females, once he uses IV estimates.
} 
rewarded on the labor market.

\subsection{Heterogeneous responses}

In summary, once we control for unobserved heterogeneity, heavier European workers experience a wage penalty in the labor market. Is the negative impact of $B M I$ on earnings common across Europe, or does it vary along well defined patterns? Ceteris paribus, we might expect that being overweight or obese affects (unobserved) productivity differently in a warm than in a cold climate, possibly because weight can be debilitating in the former case and an asset in the latter case. To check this, we re-estimate our IV regressions after augmenting them with the interaction of $B M I$ with the average annual temperature in the capital city of each country in our sample, expressed as deviation from the baseline city, Madrid ${ }^{14}$. The results are shown in the first part of columns (1) and (2) of Table 4. Independently of gender, the interaction effect is negative and statistically significant, which confirms our hypothesis: being overweight in Madrid carries a penalty, but is an asset in Dublin, where the average annual temperature is 9.4 Farenheit degrees below Madrid ${ }^{15}$.

Naturally, the weather is not the only candidate to account for the heterogeneity in the relationship between obesity and wages in Europe. An alternative is GDP per capita. When we re-estimate our wage regressions after augmenting them with the interaction between individual $B M I$ and GDP per capita in PPP - 1998 values - we find the results in the second part of columns (1) and (2) of Table 4 : the interaction is positive and statistically significant, suggesting that higher GDP per capita is associated with a lower wage penalty and even a premium for overweight and obese workers. This parallelism with the findings based on the weather should not

\footnotetext{
${ }^{14}$ The instruments are the average BMI of family members and the interaction of this variable with the weather.

${ }^{15}$ Average temperature in Madrid is $57.6 \mathrm{~F}$, compared to $48.2 \mathrm{~F}$ in Dublin. Data on average 24 hour temperatures in the capital cities are from http://worldweather.com.
} 
surprise, as the classification of countries into the "GDP per capita higher than or lower than Spain" groups contains the same countries classified into the "warmer or colder climate than in Spain" groups, with the single exception of Italy: Rome is on average slightly warmer than Madrid but Italy has a higher GDP per capita than Spain.

Table 4: IV estimates, by gender - with interactions

\begin{tabular}{ccccc}
\hline \hline & & & & \\
& FeMales & Males & Females & Males \\
& $(1)$ & $(2)$ & $(3)$ & $(4)$ \\
& & & & \\
BMI & -0.024 & -0.029 & -0.018 & -0.023 \\
BMI*WEATHER & -0.005 & -0.86 & 3.21 & 3.65 \\
& 3.78 & 3.92 & -0.007 & -0.008 \\
& & & & \\
BMI & -0.036 & -0.063 & -0.036 & -0.051 \\
BMI*GDP & 3.54 & 3.57 & 4.26 & 3.00 \\
& 0.210 & 0.388 & 0.270 & 0.348 \\
& 3.82 & 3.44 & 4.60 & 2.22 \\
OBS. & 17,202 & 24,550 & 15,465 & 22,788 \\
\hline \hline
\end{tabular}

Note: see Table 2

A potential concern with the estimates in Table 4 is that we are including data from countries - Denmark, Belgium and Finland - where the selected instrument can be computed only for a minority of the available observations. However, as shown in columns (3) and (4) of Table 4, our results are robust to the exclusion of these countries from the sample.

These patterns suggest that - for the purposes of this study - a meaningful grouping of countries is between the countries of the "olive belt" - Greece, Italy, Portugal and Spain - and the countries of the "beer belt" in Central and Northern Europe. The estimates presented in Table 5 allow the coefficient associated to the $B M I$ to vary across the two groups of countries. For 
the latter group, we also present estimates which exclude Denmark, Belgium and Finland. A clear pattern emerges: independently of gender, the impact of obesity on wages is negative and statistically significant in the countries of the "olive belt", positive and almost always statistically significant in the countries of the "beer belt".

Table 5: IV estimates, by gender

\begin{tabular}{ccccccc}
\hline \hline & \multicolumn{3}{c}{ FEMALES } & \multicolumn{3}{c}{ MALES } \\
& \multicolumn{3}{c}{ - IV - } & & \multicolumn{3}{c}{- IV - } \\
\cline { 2 - 7 } & 1 & 2 & 3 & 4 & 5 & 6 \\
BMI - OLIVE BELT & -0.056 & -0.041 & -0.035 & -0.093 & -0.056 & -0.060 \\
BMI - BEER BELT & 5.15 & 4.81 & 4.40 & 5.47 & 4.26 & 4.32 \\
BMI - IRELAND \& AUSTRIA & 0.017 & 0.018 & 0.027 & 0.024 & 0.054 & 0.076 \\
& 0.028 & 0.032 & 0.039 & 0.024 & 0.058 & 0.065 \\
Obs. & 2.05 & 2.51 & 3.22 & 0.76 & 1.79 & 1.83 \\
\hline \hline
\end{tabular}

Note: see Table 2 .

\section{Conclusion}

The purpose of the paper was to investigate to what extent European overweight workers experience a wage penalty in the labor market. Some studies have shown that obesity is an handicap to social advancement, especially for women. Existing research, however, focuses mainly on the US and the UK.

We have used data from the European Community Household Panel - a comparative dataset covering most European countries - to investigate the impact of obesity on wages in 9 European countries, ranging from Finland to Spain. We have used ordinary least squares estimates as well as fixed effects and instrumental variables estimates. The bottom line is that - when we pool all countries and years to estimate a common effect - the impact of obesity on wages is negative and statistically significant, independently of 
gender.

Given the nature of European labor markets, however, we suspect that a common impact of obesity on wages is overly restrictive. We have suggested two dimensions of cross-country variation in such impact, one related to a measure of average annual temperature in the country, and the other related to GDP per person. We have found that the negative relationship between $B M I$ and wages is typical of the countries belonging to the "olive belt" of Europe. In Northern and Central Europe, a higher BMI favors individual wages.

We have speculated that the interaction between the weather and the $B M I$ can help explain the contrast in results between Northern and Southern Europe. A deeper understanding of such contrast, however, is beyond the range of the current exploration, and must be left to future research. 


\section{References}

Aigner, D., And G. Cain (1977): "Statistical Theories of Discrimination in Labor Markets," Industrial and Labor Relations Review, 30, 175-187.

Averett, S., And S. Korenman (1996): "The Economic Reality of the Beauty Myth," Journal of Human Resources, 31(2), 304-330.

(1999): "Black-White Differences in Social and Economic Consequences of Obesity," International Journal of Obesity, 23, 166- 173.

Baum, C., AND W. Ford (2004): "The Wage Effects of Obesity: A Longitudinal Study," Health Economics, 13(9), 885-99.

Becker, G.(1957): The Economics of Discrimination. University of Chicago Press, Chicago, I, 2ième edition, 1971.

Becker, G. S., And K. Murphy (1988): "A Theory of Rational Addiction," Journal of Political Economy, 96(4), 675-700.

Behrman, J., And M. Rosenzweig (2001): "The Returns to Increasing Body Weight," PIER Working Paper 01-052.

Borghans, L., And B. Golsteyn (2005): "Time Discounting and the Body Mass Index," IZA Discussion Paper No. 1597.

Bound, J., C. Brown, and N. Mathiowetz (2002): "Measurement Error in Survey Data," in In Handbook of Econometrics, ed. by J. Heckman, and E. Leamer, pp. 3705-3843, New York. Springer-Verlag.

Cawley, J. (2000): "An Instrumental Variables Approach to Measuring the Effect of Obesity on Employment Disability," Health Services Research, 35(5), 11591179. 
(2004): "The Impact of Obesity on Wages," Journal of Human Resources, $39(2), 451-474$.

Cawley, J., And S. Danziger (2000): "Obesity as a Barrier to Employment and Earnings for Current and Former Welfare Recipients," NBER Working Paper 10508 .

Cawley, J., and M.M. Grabkal, and D.R. Lillard (2005: 'A comparison of the Relationships Between Obesity and Earnings in the US and Germany," Journal of Applied Social Science Studies, forthcoming.

Conley, D., And R. Glauber (2005): "Gender, Body Mass and Economic Status," NBER Working Paper 11343.

Chevalier, A., And I. Walker (1999): "Further Results on the Returns to Education in the UK," Warwick, UK. Université de Warwick.

Dockner, E., And G. Feichtinger (1993): "Cyclical Consumption Patterns and Rational Addiction," American Economic Review, 83, 256-263.

Evans, W., and E. Montgomery (1994): "The Effects of Cigarette Smoking on Wages," Industrial and Labor Relations Review, 50(3), 493-509.

FAHR, R. (2004): "Discrimination by Physical Appearance Across Europe," Working paper.

Fersterer, J., And R. Winter-Ebmer (2003): "Smoking, Discount Rates, and Returns to Education," Economics of Education Review, 22(6), 561-566.

Filozof, C., M. Fernández Pinilla, And A. Fernández-Cruz (2004): "Smoking Cessation and Weight Gain," Obesity Reviews, 5(2), 95-103.

Flegal, K., M. Carroll, R. Kuczmarski, and C. Johnson (1998): "Overweight and Obesity in the United States: Prevalence and Trends, 1960-1994," International Journal of Obesity and Related Metabolic Disorders, 22, 39-47. 
Grilo, C.M., and M.F. Pogue-Geile (1991): "The nature of environmental influences on weight and obesity: A behavior genetic analysis," Psychological Bulletin, 110(3), 520-537.

Halpern, M., R. Shikiar, A. Rentz, and Z. Khan (2001): "Impact of Smoking Status on Workplace Absenteeism and Productivity," Tobacco Control, 10(3), 233-238.

Hamermesh, D., And J. Biddle (1994): "Beauty and the Labor Market," American Economic Review, 84, 1174-94.

Harper, B. (2000): "Beauty, Stature and the Labour Market: A British Cohort Study," Oxford Bulletin of Economics and Statistics, 62, 771-800.

Haskins, K., And H. Ransford (1999): "The Relationship Between Weight and Career Payoffs Among Women," Sociological Forum, 14(2), 295-318.

Hayes, D., And C. Ross (1986): "Body and Mind: The Effect of Exercise, Overweight, and Physical Health on Psychological Well-Being," Journal Of Health And Social Behavior, 27(4), 387-400.

Lakdawalla, D., and T. Philipson (2002): "The Growth of Obesity and Technological Change: A Theoretical and Empirical Analysis," NBER Working Paper Series, 8946.

Lee, L., And J. Sepanski (1995): "Estimation of Linear and Nonlinear Errors-inVariables Models Using Validation Data," Journal of the American Statistical Association, 90, 130-140.

Levy, A. (2002): "Rational Eating: Can It Lead to Overweightness Or Underweightness?," Journal of Health Economics, 21, 887-899.

LoH, E. (1993): "The Economic Effects of Physical Appearance," Social Science Quarterly, 74(2), 420-438. 
Locatelli, E., And V. Pasqua (1993): "The European Community Household Panel (ECHP): elements for users with special focus on labour and household economics," ChilD working paper n.24/2001 420-438.

Martinez-Gonzales, M., J. Martinez, F. Hu, M. Gibney, and J. Kearney (1999): "Physical Inactivity, Sedentary Lifestyle and Obesity in the European Union," International Journal of Obesity, pp. 1192-1201.

McLean, R., And M. Moon (1980): "Health, Obesity, and Earnings," American Journal of Public Health, 70(9), 1006-1009.

Michaud, P., And A. Van Soest (2005): "Obesity, Health and Socio-Economic Status: An International Comparison," Center for Financial Studies, Working Paper.

Mizoue, T., R. Ued, N. Tokui, Y. Hino, and T. Yoshimura (1998): "Body Mass Decrease After Initial Gain Following Smoking Cessation," International Journal of Epidemiololy, 27, 984-988.

Molarius, A., J. Seidell, K. Kuulasmaa, A. Dobson, and S. Sans (1997): "Smoking and Relative Body Weight: An International Perspective from the WHO MONICA Project.," Journal of Epidemioly and Community Health.

Munasinghe, L., And N. Sicherman (2000): "Why Do Dancers Smoke? Time Preference, Occupational Choice, and Wage Growth," NBER Working Paper No. 7542.

O'Hara, P., J. Connett, W. Lee, M. Nides, R. Murray, and R. Wise (1998): "Early and Late Weight Gain Following Smoking Cessation in the Lung Health Study," American Journal of Epidemiology, 148, 821-830.

Pagan, J., And A. Davlia (1997): "Obesity, Occupational Attainment, and Earnings," Social Science Quarterly, 78(3), 756-770. 
Persico, N., A. Postlewaite, and D. Silverman (2004): "The Effect of Adolescent Experience on Labor Market Outcomes: The Case of Height," Journal of Political Economy, 112, 1019.

Pinhey, T., D. Rubinstein, and R. Colfax (1997): "Overweight and Happiness: The Reflected Selfappraisal Hypothesis Reconsidered," Social Science Quarterly, 3(78), $747-755$.

Register, C. A., And D. Williams

(1990): "Wage Effects of Obesity Among Young Workers," Social Science Quarterly, 71.(1), 130-141.

Ross, C. (1994): "Overweight and Depression," Journal Of Health And Social Behavior, 35(1), 63-79.

Sargent, J., and D. Blanchflower (1994): "Obesity and Stature in Adolescence and Earnings in Young Adulthood. Analysis of a British Birth Cohort," Archives of Pediatrics and Adolescent Medicine, 148, 681-687.

SousA, S. (2005): "Does Size Matter? A Propensity Score Approach to the Effect of BMI on Labour Market Outcomes," ESPE 2005.

Stam-Moraga, M., J. Kolanowski, M. Dramaix, G. De Backer, M. KorNitZer, AND E. Muls (1999): "Sociodemographic and Nutritional Determinants of Obesity in Belgium," International Journal of Obesity, 23, 1-9.

Viscusi, W., AND J. Hersch (2001): "Cigarette Smoking as Job Risk Takers," Review of Economic and Statistics, 83(2), 269-280.

Vogler, G.P., and T. Sorensen, and A.J. Stunkard, and M.R. SriniVASAN, AND D.C. RAO (1995): "Influences of genes and shared family environment on adult body mass index assessed in an adoption study by a comprehensive path," International Journal of Obesity, 19, 40-45. 
Wardle, J., and J. Griffith (2001): "Socioeconomic Status and Weight Control Practices in British Adults," Journal of Epidemiology and Community Health, $55,185-190$.

\section{Appendix}

\section{- Data}

The European Community Household Panel (ECHP) is a survey - running from 1994 to 2001- based on annual interviewees of a representative panel of households and adult individuals - aged 16 years and over - in each country. Fifteen European Countries are included: Austria, Belgium, Denmark, Finland, France, Germany, Greece, Ireland, Italy, Luxembourg, the Netherlands, Portugal, Spain, Sweden and the United Kingdom. The information is stored in the "Production data base" that consists of 6 files : household file, personal file, register file, longitudinal link file, country file, and relationship file. Members of the same family are matched by using the relationship file. There is a record in the file for each pair of individuals in the same household, with information about the type of relationship they have (ie, partner, child, parents, siblings, grandchild, grandparent) ${ }^{16}$.

Information on individual'weight and height are available since 1998 and for 9 countries only. Importantly, the use of the BMI of a biological family member as instrument for individual BMI reduces the available sample rather drastically. This is because respondents living (i) alone, (ii) in a couple or (iii) in couple with children aged less than 16, are excluded from our analysis. We report in the following table the sample size for OLS and IV estimates, by country.

\footnotetext{
${ }^{16}$ See Locatelli M., Moscato V., Pasqua S., 2001, for further details
} 
- Tables

Table 6: Sample size, ECHP, 1998-2001

\begin{tabular}{lcccc}
\hline & \multicolumn{2}{c}{ FEMALES } & \multicolumn{2}{c}{ MALES } \\
& OLS & $I V$ & OLS & $I V$ \\
\cline { 2 - 5 } Full sample & 35503 & 17202 & 47743 & 24550 \\
Denmark & 2919 & 467 & 3095 & 467 \\
Belgium & 1867 & 544 & 2165 & 651 \\
Ireland & 2972 & 1724 & 3863 & 2277 \\
Finland & 3027 & 726 & 2768 & 644 \\
Italy & 5999 & 3307 & 8960 & 5074 \\
Greece & 3267 & 1845 & 4930 & 2904 \\
Spain & 5142 & 3013 & 8537 & 4878 \\
Portugal & 6518 & 3797 & 8311 & 4928 \\
Austria & 3792 & 1779 & 5114 & 2727 \\
\hline
\end{tabular}


Table 7: Summary statistics, ECHP, 1998-2001

\begin{tabular}{lcc}
\hline \hline & MALES & FEMALES \\
\hline Net Hourly wage & 8.45 & 7.45 \\
Age & 38.49 & 37.88 \\
Hours & 41.46 & 36.48 \\
Secondary level of education \% & 35.52 & 38.14 \\
Tertiary level of education \% & 15.83 & 22.17 \\
& & \\
\hline BMI & 25.36 & 23.31 \\
Weight & 77.56 & 62.46 \\
Height & 174.84 & 163.72 \\
Overweight & 0.43 & 0.21 \\
Obesity & 0.07 & 0.05 \\
\hline Obs. & 35,503 & 47,743 \\
\hline
\end{tabular}

Table 8: OLS estimates, by gender

\begin{tabular}{|c|c|c|c|c|c|c|}
\hline & \multicolumn{3}{|c|}{ FEMALES } & \multicolumn{3}{|c|}{ MALES } \\
\hline & 1 & 2 & 3 & 4 & 5 & 6 \\
\hline$B M I$ & $\begin{array}{c}-0.0147 \\
12.69\end{array}$ & $\begin{array}{c}-0.0054 \\
6.73\end{array}$ & $\begin{array}{c}-0.0016 \\
2.30\end{array}$ & $\begin{array}{c}-0.0011 \\
1.17\end{array}$ & $\begin{array}{c}0.003 \\
4.06\end{array}$ & $\begin{array}{c}0.004 \\
5.36\end{array}$ \\
\hline Age & 0.043 & 0.048 & 0.039 & 0.062 & 0.041 & 0.033 \\
\hline Age, squared & -0.0003 & -0.0004 & -0.0003 & -0.0006 & -0.0006 & -0.0002 \\
\hline Partime & 11.43 & $\begin{array}{c}15.98 \\
0.058\end{array}$ & $\begin{array}{c}14.21 \\
0.019\end{array}$ & 24.97 & $\begin{array}{c}16.95 \\
0.090\end{array}$ & $\begin{array}{c}14.98 \\
0.066\end{array}$ \\
\hline Living in a couple & & $\begin{array}{c}6.48 \\
0.012\end{array}$ & $\begin{array}{c}2.35 \\
0.023\end{array}$ & & $\begin{array}{c}3.87 \\
0.100 \\
1365\end{array}$ & $\begin{array}{l}2.97 \\
0.093\end{array}$ \\
\hline Children under 12 & & 0.016 & 0.017 & & -0.008 & 0.0230 \\
\hline Secondary level education & & $\begin{array}{l}2.46 \\
0.327 \\
48.24\end{array}$ & $\begin{array}{l}2.16 \\
0.166 \\
23.94\end{array}$ & & $\begin{array}{l}1.80 \\
0.233 \\
36.39\end{array}$ & $\begin{array}{l}3.96 \\
0.138 \\
22.75\end{array}$ \\
\hline Third level education & & 0.703 & 0.328 & & 0.581 & 0.308 \\
\hline Bad Health & & -0.057 & -0.043 & & -0.139 & -0.115 \\
\hline Hampered in daily activity & & -0.059 & -0.042 & & -0.078 & -0.055 \\
\hline Current smoker & & $\begin{array}{l}5.51 \\
0.001\end{array}$ & $\begin{array}{l}4.16 \\
0.001\end{array}$ & & $\begin{array}{c}7.92 \\
-0.0012\end{array}$ & $\begin{array}{c}6.01 \\
-0.0007\end{array}$ \\
\hline Observations & & $\begin{array}{r}0.00 \\
35,503\end{array}$ & & & $\frac{5.99}{47,743}$ & \\
\hline
\end{tabular}


Table 9: First-Stage estimate of BMI

\begin{tabular}{|c|c|c|c|c|c|c|}
\hline & & EMALE & & & $\overline{\text { MALES }}$ & \\
\hline & 1 & 2 & 3 & 4 & 5 & 6 \\
\hline$B M I$ family members & $\begin{array}{c}0.296 \\
22.20\end{array}$ & $\begin{array}{c}0.302 \\
22.26\end{array}$ & $\begin{array}{c}0.294 \\
22.25\end{array}$ & $\begin{array}{c}0.198 \\
22.40\end{array}$ & $\begin{array}{c}0.021 \\
24.49\end{array}$ & $\begin{array}{l}0.214 \\
24.15\end{array}$ \\
\hline Age & 0.261 & 0.211 & 0.219 & 0.293 & 0.265 & 0.259 \\
\hline Age, squared & -0.001 & $\begin{array}{c}9.26 \\
-0.001\end{array}$ & $\begin{array}{c}9.96 \\
-0.001\end{array}$ & $\begin{array}{r}20.80 \\
-0.002\end{array}$ & $\begin{array}{r}17.83 \\
-0.002\end{array}$ & $\begin{array}{r}17.57 \\
-0.002\end{array}$ \\
\hline Partime & & 0.085 & 0.086 & & 0.308 & 0.314 \\
\hline Living in a couple & & $\begin{array}{l}0.670 \\
\dot{7} .06\end{array}$ & $\begin{array}{l}0.621 \\
6.57\end{array}$ & & $\begin{array}{c}0.889 \\
9.24\end{array}$ & 0.845 \\
\hline Children under 12 & & 0.184 & 0.157 & & 0.100 & 0.086 \\
\hline Secondary level education & & -0.763 & -0.521 & & -0.090 & -0.093 \\
\hline Third level education & & -1.081 & -0.630 & & -0.331 & -0.311 \\
\hline Bad Health & & -0.141 & -0.130 & & -0.156 & -0.0158 \\
\hline Hampered in daily activity & & 0.589 & 0.528 & & -0.080 & -0.061 \\
\hline Current smoker & & -0.011 & -0.010 & & $\begin{array}{c}-0.012 \\
-0.59\end{array}$ & $\begin{array}{c}0.02 \\
-0.012 \\
5.75\end{array}$ \\
\hline Observations & & 17,202 & & & 24,550 & \\
\hline
\end{tabular}

Table 10: IV estimates, Full specification

\begin{tabular}{|c|c|c|c|c|c|c|}
\hline & \multicolumn{3}{|c|}{ FEMALES } & \multicolumn{3}{|c|}{ MALES } \\
\hline & 1 & 2 & 3 & 4 & 5 & 6 \\
\hline$B M I$ & $\begin{array}{c}-0.026 \\
4.97\end{array}$ & $\begin{array}{c}-0.017 \\
3.93\end{array}$ & $\begin{array}{c}-0.010 \\
2.47\end{array}$ & $\begin{array}{l}-0.059 \\
8.83\end{array}$ & $\begin{array}{c}-0.018 \\
3.60\end{array}$ & $\begin{array}{c}-0.013 \\
2.64\end{array}$ \\
\hline Age & $\begin{array}{l}0.049 \\
14.40\end{array}$ & $\begin{array}{l}0.042 \\
14.44\end{array}$ & $\begin{array}{l}0.034 \\
13.09\end{array}$ & $\begin{array}{l}0.058 \\
17.82\end{array}$ & $\begin{array}{l}0.037 \\
13.98\end{array}$ & $\begin{array}{l}0.032 \\
13.47\end{array}$ \\
\hline Age, squared & $\begin{array}{r}-0.000 \\
10.00\end{array}$ & $\begin{array}{c}-0.000 \\
8.88\end{array}$ & $\begin{array}{l}-0.000 \\
8.24\end{array}$ & $\begin{array}{r}-0.000 \\
12.10\end{array}$ & -0.000 & $\begin{array}{c}-0.000 \\
9.23\end{array}$ \\
\hline Partime & & $\begin{array}{l}0.077 \\
5.22\end{array}$ & $\begin{array}{l}0.034 \\
2.66\end{array}$ & & $\begin{array}{l}0.036 \\
1.28\end{array}$ & 0.003 \\
\hline Living in a couple & & 0.011 & 0.032 & & 0.148 & 0.123 \\
\hline Children under 12 & & -0.021 & -0.014 & & $\begin{array}{c}-0.036 \\
3.93\end{array}$ & $\begin{array}{l}-0.012 \\
1.51\end{array}$ \\
\hline Secondary level education & & $\begin{array}{l}0.287 \\
28.56\end{array}$ & $\begin{array}{l}0.131 \\
13.34\end{array}$ & & $\begin{array}{l}0.192 \\
21.30\end{array}$ & $\begin{array}{l}0.114 \\
13.19\end{array}$ \\
\hline Third level education & & 0.692 & 0.318 & & 0.544 & 0.284 \\
\hline Bad Health & & $\begin{array}{c}-0.026 \\
0.92\end{array}$ & $\begin{array}{c}-0.008 \\
0.34\end{array}$ & & -0.112 & $\begin{array}{r}-0.099 \\
4.88\end{array}$ \\
\hline Hampered in daily activity & & $\begin{array}{c}-0.074 \\
4.20\end{array}$ & $\begin{array}{c}-0.053 \\
3.28\end{array}$ & & -0.115 & $\begin{array}{c}-0.092 \\
7.25\end{array}$ \\
\hline Current smoker & & $\begin{array}{c}0.003 \\
5.75\end{array}$ & $\begin{array}{c}0.002 \\
5.48\end{array}$ & & $\begin{array}{c}-0.001 \\
4.33\end{array}$ & $\begin{array}{c}-0.000 \\
2.94\end{array}$ \\
\hline Observations & & 17,202 & & & 24,550 & \\
\hline
\end{tabular}

